\title{
The Economic Analysis of the Law in the Sphere of Public Law Regulation of Activity of Economic Entities
}

\author{
S.P. Bortnikov ${ }^{1, *}$ \\ Corresponding author: serg-bortnikov@yandex.ru \\ ${ }^{1}$ Samara State University of Economics, Samara, Russia
}

\begin{abstract}
The relevance of work is caused by importance of correlation of the legal methods established by the power and the economic maintenance of the adjustable relations. In article the general approaches to legal regulation of economy, on the one hand, and to the economic analysis of law - with another are analyzed. The author argues the point of view according to which the correlation "law and economy" and differentiation of the economic analysis of continental and common law is necessary. Arguments in support of the centralized legal regulation and economic management of economy are adduced. Further author's main characteristics "the economic analysis of law" in the changing state of the Russian Federation, since 1990 are granted. In the most general sense methodological and ideological bases of approach to definition of legal regulation of economic management in the socialist and capitalist state are defined. According to the author, capitalism is also the deadlock direction of economic development. The approach existing in an economics represents attempt to extend phenomena of the neoclassical economic theory and neo institutionalism to the spheres of the public relations which are not connected with economy (i.e. economic approach to all social problems). Demand is not exclusively economic category, it extends also to the sphere of the right which is estimated also on availability, the price, alternative costs, usefulness. The author proves need of the researches covering boundary subject of law and economy. Arguments in support of this point of view are adduced. The conclusion is in conclusion drawn that need of researches on a joint of the right and economy is obvious now, and it concerns not only legal, but also equally economic science. At the same time interaction of sciences has to be carried out as equals, and amendments have to concern both fields of knowledge. In this regard researches "the rights and economies" can become one of the most perspective directions of development within both law, and economy.
\end{abstract}

Keywords: law and economic, the economic analysis of law, institutional economy, price, costs, benefits.

\section{Introduction}

In the last half century, Law and Economics (L\&E) has become one of the most influential movements in legal academia. One of main goals of a research is understanding of parameters of mutual influence of the right and economy, their real joint action in public life. The difficulty consists in determination of distinctions of manifestation of the continental right and common law in the economic relations.

For any lawyer the rule of law is not accident and an optional element of legal ideology, it is firm. The economic feasibility and practical benefits cannot be above the law. No economic cost intensity and low cost efficiency should allow to legalize drugs, prostitution, trade in children or bodies, refusal of protection of integrity of human beings and life. The law is inseparably linked with morals, it dominates at adoption of the relevant statutory act. [1] Economic examination of the statutory act in the course of its acceptance should not lead to absolutization of cost efficiency (the economic logic, and true criterion of the right and law enforcements - cost efficiency is the basis for functioning of the right), etc.

Lag of legal regulation from rates of social and economic development was one of factors which caused emergence and wide circulation of the new direction of researches of legal institutes from positions of economic conditionality of the right differing in radical approaches and nigilistic estimates of the traditional legal methodology of researches which is saved up for several centuries by schools of sciences of various legal systems.

\section{Problem Statement}

The modern economy at different schools is considered and as economy of division of labor, and as set of financial processes, and as distribution of the surplus value, and as correlation of supply and demand, consumption and so forth.

Development within the operating economic paradigm is based on deepening of division of labor which is a basis of model and in science is called scientific and technical progress. If it is simpler to be expressed - the more professions in a certain territory (the city, the state, the planet), the subject is richer. An indispensable condition of this process are innovations which are meant as emergence of both new products, and new production technologies. Delay of the specified processes or their stop is considered in modern model of economy as crisis. Simplification of a system 
division of labor (its degradation) as, for example, it was in the USSR and the Russian Federation in the 90th years, is perceived as economic accident. The model of economic development in the USSR and the USA, Soviet and the western systems of division of labor, was same - model of scientific and technical progress. The difference of socialism was only in other system of redistribution that is well visible on economic races of the USSR and the USA of the middle of the XX century.

Modern processes of digitalization of economy and the social sphere, including in questions of legal regulation, put new calls before the researcher and the law enforcement official. Replacement of the person by the COMPUTER program, digitization of the personality, "capture" with robots of traditional professional spheres of the person affects employment in general and division of labor, in particular [2].

Division of labor of the person inevitably involves increase in risks of the producer which has to be built in harder and harder production chain. If there are no mechanisms of decrease in these risks, then at some point deepening of division of labor becomes impossible - the system passes into a condition of deep crisis. Replacement of the person with the program or the mechanism not only reduces the specified risks, but changes the system of classical factors of production and and relations of production. Often the right is not ready to such changes which are already existing in economy and the social sphere yet. In the right there is no necessary terms framework, the essence and the principles of the new institutional relations is not defined.

Respectively, within the closed economic system (which is not interacting with the outside world), natural deepening of division of labor can develop only to some fixed level, further an innovation cease to pay off and scientific and technical progress slows down in the beginning, and then stops. In case the economic system begins to interact with the outside world, then natural deepening of division of labor continues to develop, but also to the certain fixed level. A classical example - Singapore which became "economic miracle" only thanks to the fact that the USA opened for them the markets and also the USA and Europe in the 90th years when owing to the collapse of the USSR and disintegration of a socialist system the new, undeveloped markets in the form of several independent states trying to be built in a capitalist system were formed. This thesis about restriction of deepening of division of labor in the closed system for the first time was formulated by Adam Smith in the second half of the 18th century, then this subject within Marxism was developed at the end of XIX - the beginning of the 20th century Rosa Luxemburg.

\section{Research Questions}

In jurisprudence, including science of constitutional right which has to use and uses methods of researches and conclusions of other sciences there is the object of studying. In what belongs to economy science of constitutional right first of all not the economy in itself (constitutional or unconstitutional), and legal regulation of bases of the economic (social and economic) relations in society interests (etc. other jurisprudence is engaged in the private economic, economic, enterprise, family relations). The science has to investigate that set of constitutional precepts of law and institutes which is used for regulation of the economic relations; to establish their sufficiency or lameness in certain specific conditions taking into account stimulation of progressive development of the country and ensuring social justice (we see also in Russia insufficiency or inaccuracies on many major questions of the economic relations) [3, 4]. She has to offer necessary additional norms or institutes, to advise to exclude become obsolete. The science has to investigate the social and legal content of constitutional precepts of law and institutes and to offer such thoroughly thought over [5], to some extent partially used in practice and if it is possible - in an experimental order, legal formulations which will correspond to best set social and economic tasks. It always became in the Russian science and a little foreign constitutionalists just because of lack of the relevant provisions in constitutions of their states.

So, for example, the world of private law as absolutely autonomous and transcendental system built and developing only on the basis of interpretation of certain "sacred texts" (whether it be the Roman sources or national civil codes), historical researches and formal logic, long ago in the past. In science of foreign countries the set of the competing scientific methodologies focusing attention on various aspects of substantial rationality of the right actively develops (for example, law of interests and values in Germany, legal pragmatism and the economic analysis of the right in the USA, school of critical legal researches, etc.). The research in which the author does not analyze right policy issues in the context of this or that legal problem becomes a rarity if only it initially has no especially historical character [6].

The right gets all into bigger number of spheres of human life. Kind of we treated this phenomenon, life of society becomes more and more dependent on success of external, legal regulation. In such conditions law-making mistakes too expensive cost society. Those countries in which the government makes less than such mistakes and are produced by a better "legal product" (regulation and the system of its carrying out in life), make the way in life to prosperity and vice versa. Respectively, in the 20th century sharply there was a question of development of the theory and, the most important, methodologies of the political and legal choice.

\section{Purpose of the Study}

The issue of planning and economic freedom always interacts with the institution of entrepreneurial risk and responsibility: the entrepreneur who assumes the responsibility for the risk must decide independently, which 
experiments he is ready to perform, and which ones he is not. Involvement in the process of private households planning removes this risk. If the government forces private entrepreneurs to take certain actions, it will have to assume responsibility for the damage that individual entrepreneurs will incur as a result of forced behavior.

Given the existence of a large public economic sector, a public entity will be forced to manage as an investor and in private sector to: plan, manage, bear risks, etc. But the government in the process of performing its own functions still has an effect on the economy of the country as a whole, which will lead to the development of a common economic policy that will cover the whole range of economic activities (both public and private sectors of the economy). It is important, in this case, to answer the question about the efficiency of the public sector and the soundness of its existence [4].

In the process of elaborating economic policy and choosing the means of influencing the economy, the government should decide the issues of its effectiveness, responsibility for the administrative decision made, and so on. It was also possible to apply the existing principle of the tax law on efficiency: so that the expenditures for taxes collecting procedure were less than the amount of the taxes actually collected. The same way, the management efficiency exactly in the field of management should be correlated with the costs of its implementation. An official cannot assume the functions of an entrepreneur. And, on the contrary, the government can more effectively perform the functions of the public administration than an entrepreneur. The transfer of these functions to the entrepreneur either will make him an official, or will be ineffective at all.

Prospective state planning creates certain guarantees and incentives for private farms. In a market economy, without the participation of the government, a private entrepreneur has no guarantees and confidence in the future. The horizon period of its planning is extremely limited: a year, at most - two. The dependence on market conditions, spontaneous processes, actions of major players results in uncertainty. The state inflationary policy, fiscal reflection also does not add confidence. On the contrary, the state plan intended for 5-7, or better 10 years, determines the conditions of management, sets tasks and objectives, assign macro markers in the economy.

But not only the intervention of the proper government in the economy and economic activities of entrepreneurs should be mentioned here. But similar consequences and meanings also experience interventions of trade unions, consumer protection societies, etc.

\section{Research Methods}

As the population of Earth by definition is limited, and all other mechanisms of reduction of risk of the producer only redistribute them in an economic system, there is a limit of division of labor and, therefore, scientific and technical progress. From here a conclusion - capitalism is limited in time of the existence as demands continuous expansion of sales markets (in general, history of capitalism is story of expansion of the markets). All theoretical creation of Marx was only attempt to answer a question: "If capitalism will die, what will be after capitalism?".

With socialism a situation more difficult as it, theoretically, within the public nature of economy (in which there is no private property on means of production) can pass to other paradigm of development without change of social and political model.

Development of Marxism from the moment of its emergence in the middle of the 19th century went on two main ideological lines: search of new proofs and signs of the end of capitalism and models of creation of post-capitalist society. Adam Smith's thesis given above gained real development only in Rosa Luxemburg's works, but after her death this subject was completely tabooed, and not only in the West (where even the mention of a possibility of "the end of capitalism" since a certain moment became unacceptable for ideological reasons), but also in the USSR, and then and in the world system of socialism where this subject was not welcomed in connection with disagreements between Rosa Luxemburg and V.I. Lenin. Besides, even within that economic and political theory which was developed by Vladimir Ilyich Lenin and then Iosif Vissarionovich Stalin, discussions about options of development were possible exactly until the Communist Party actually tabooed development of Marxism (therefore today's communists try to explain processes of the 21 st century through a prism of economic theories of the 19th century, adjusting modern events to these theories without their any recognition).

The taboo on a mention of the end of capitalism resulted in impossibility to explain the reasons of a modern economic crisis within the western economic theory as in it there are no tools for its description. And here in political economy these tools are available.

Thus, development within a paradigm of scientific and technical progress is possible only in process of use of mechanisms of reduction of risk of producers. Such mechanisms it was invented only three: crediting of the producer (risks are partially transferred to a banking system), expansion of sales markets of products (risks of the producer in an initial economic system decrease), crediting of the consumer (risks of the producer due to their redistribution between other participants of economic process decrease). 


\section{Findings}

\subsection{Modern capitalism and imperialism as last stage of its development}

Lenin defined that modern capitalism "becomes monopoly capitalism everywhere". "Capitalism turned into the world system of colonial oppression and a financial suffocation of the vast majority of world's population a handful of the "advanced" countries" [2]. This domination over the world of several imperialistic powers - the biggest barrier not only to economic and social progress of less developed countries, but also to the solution of pressing problems which negatively influence mankind in general but also now destroy the planet.

So, need of its expansion for development continuation is an economic consequence of restriction of division of labor in the closed economic system. The impossibility of such expansion leads sooner or later to development crisis which essentially differs from traditional cyclic crises (overproduction crises) which are in detail described as within political economy (since the end of the 19th century - mainly Marxist), and economics theory. In neo economy this crisis received the name of crisis of falling of efficiency of the capital as its external manifestation - fast falling of a possibility of reproduction of the capital, that is natural (but not due to redistribution) receiving profit on it. Its basic feature is that it is possible to stop it only due to significant reduction of risk of producers, and it is possible only by expansion of sales markets.

As a result of "reaganomics" structural disproportions in world (coinciding today with the American process area) economy and directly in the USA grew to the enormous sizes. First of all it concerns discrepancy of really located income of households to their expenses (that is to the standard of living). Today the average income of the American households on the purchasing power is at the level of 1962 as all this time growth of living standards of the population happened due to growth of a debt (private and state). The average debt of the American household exceeds $120 \%$ of the level of its revenue. And, at last, the American households in total spend for 3 trillion dollars more, than receive. Until income and expenses do not come to a condition of relative balance, crisis will continue, and falling of expenses at the same time has to be about 30-35\% for world economy, about 50\% - for the European Union and about 55-60\% - for the USA [7].

Reduction of income in terms of division of labor corresponds to reduction of number of consumers, and, so the level of division of labor has to decrease. As it was noted above, today's real income of households in the USA corresponds to the level of the beginning of the 60th years, and in process of crisis development they will be reduced even stronger. Actually it means that the optimum level of the process area will be somewhere at the level of 500-800 million people.

As present infrastructure of a system of division of labor (first of all - financial) is built under the global markets, in process of decline in demand it will become unprofitable (actually it already occurred - the most part of the international financial institutions and states lives only due to issue feed). It means that disintegration of the world on several new process areas which, most likely, will be created on the basis of uniform monetary policy in this connection in a neokonomika they received the name of "currency zones" will be economic.

Theoretically, in the course of crisis and post-crisis restoration not all currency zones will be able to create fullfledged process areas.

If the new model of economic development alternative to scientific and technical progress, it is not thought up, then we are waited by repetition of history of the XX century, namely competition of new process areas with each other for sales markets, that is for a possibility of further development. However this process will begin only after more or less independent zones - that is in 20-30 years after the termination of a "sharp" stage of crisis and achievement of the minimum values of cumulative demand are created.

\subsection{What today the Russian economy why it developed in such look and as we to it came is?}

And now we will look at key indicators of the USSR for the 1980th years when allegedly there were economic calls and need of introduction of the private property on means of production and holidays of the prices appeared.

Statistics shows that on the leading indicators growth up to 1988 is fixed. Then gradual recession begins (after input of the first "market" laws).

The fact remains - till 1990 crisis was not! Crisis was created by the political decision on introduction of capitalism. What it led to, many perfectly remember as they found those times at the age of reason. Ideological approach to economy in the USSR led to tragic consequences. Originally, when reserves of a management system were not still exhausted, the economy developed mad rates. In process of growth of living standards of the population, loss of attention to economic incentives and democratization of society the economy began to lose growth rates. Wised up at the end of 20th century that the capitalist system will allow to return former growth rates, it was met with approval. "Hand" was replaced with the CPSU with "an invisible hand" of the market. Introduction of free economy in Russia turned back accident. It is impossible to write off all failures in economy only for a transition period. The transition period ended for a long time. Now rates in 1-3\% are considered as the benefit. The Soviet power began with growth rates in 15-20\% a year. Welfare of the population doubled every five years. Now we have at most 3-4\% at inflation in 8-10\%. Total assessment of the carried-out reforms in Russia, is an additional argument in favor of the central operated system which refused. First, now Russia of high rates of development of economy will never test. Experience of free market economy for several centuries in the West demonstrates to it. Secondly, free market of sample XIX became the 
country cause of accident. Thirdly, Russia, having felt some economic recovery, it will be obligatory to join in so-called business cycles, to be exact, in cycles of periodic crises. Most likely, there will be not crises of overproduction that would be rather quite good, and underproduction crises. In Russia always was and there will be everything on the contrary. Such is her mentality. The deepest complex crisis of 1998 of which the country got out five years was confirmation of this conclusion. Then destructive crisis of 2008-2009 which smoothly turns into the predicted shattering crisis followed.

\section{Conclusion}

Thus, it should be recognized that for Russia a mixed economy and a mixed society are natural. Drama, and sometimes even tragedy, occurs when passionate "purists" come to power - politicians who want to see Russia as a "pure" society (no matter how: communist, capitalistic or any other kind of society) and who do not spare no expenses or people on the way to achieving this goal. From this perspective on the world, only two kinds of movement are recognized: forward (progress) or backward (reaction). Within the framework of such a worldview, we want to note that the concept of "catching-up" modernization arises. In fact, Russia needs not a "catching-up", but an "evolutionary" modernization, ensuring continuity and systemic development over the time, as well as a "diffusion" modernization, ensuring the spread of positive innovations among all areas of the socio-economic space of the country [8].

\section{References}

1. G. Bruggemeier, Tort Law of the European Union. Alphen aan den Rijn: Wolters Kluwer (2015).

2. T.S. Ulen, N. Garoupa, The market for legal innovation: Law and economics in Europe and the United States. University of Illinois Law and Economics Research Paper, LE07-009. DOI:10.2139/ssrn.972360 (2007).

3. G.N. Andreyeva, Reflections about features of formation of the Russian theory of the constitutional regulation of the economic relations. The Constitutional and Municipal Law, 9, 3-11 (2015).

4. H.G. Manne, How law and economics was marketed in a hostile world: A very personal history. In F. Parisi \& C.K Rowley (Eds.). The origins of law and economics: essays by the founding fathers (pp. 309-327). Cheltenham: Edward Elgar. Retrieved from URL: https://ssrn.com/abstract=745944 (2005).

5. D.S. Lvov, Economics of development. Moscow: Exam (2002).

6. H. Rowen, Central intelligence briefing on the soviet economy. In E. Hoffmann \& R. Laird (Eds.). The soviet polity in the modern era (pp. 411-421). New York, N.Y.: Aldine Publishing (1984).

7. W. Weigel, Law and economics in Austria. In B. Bouckaert \& G. De Geest (Eds.). The history and methodology of law and economics, vol. I of The encyclopedia of law and economics. Northampton: Edward Elgar (2000).

8. V.I. Lenin, Imperialism as the highest stage of capitalism complete works: in $55 t$. Moscow: State publishing house of political literature (1969). 